\title{
ADDITION OF MICRONUTRIENTS TO NPK FORMULATION AND INITIAL DEVELOPMENT OF MAIZE PLANTS
}

\author{
ADIÇÃO DE MICRONUTRIENTES A FORMULADO NPK E O \\ DESENVOLVIMENTO INCIAL DE PLANTAS DE MILHO
}

\author{
Gustavo Alves SANTOS ${ }^{1}$; Gaspar Henrique KORNDORFER ${ }^{2}$; Hamilton Seron PEREIRA ${ }^{2}$; \\ Wooiklee PAYE ${ }^{3}$ \\ 1. Agrônomo, Doutor em Agronomia pelo Programa de Pós-Graduação em Agronomia - PPGA, Instituto de Ciências Agrárias, \\ Universidade Federal de Uberlândia - UFU, Uberlândia, MG, Brasil. asgustavo@ yahoo.com.br; 2. Professor, Doutor, Instituto de \\ Ciências Agrárias, Universidade Federal de Uberlândia - UFU, Uberlândia, MG, Brasil. 3. Doutorando, Agricultural Center, Louisiana \\ State University - LSU, Baton Rouge, LA, Estados Unidos.
}

\begin{abstract}
Micronutrients are essential nutrients for plant growth and development; however, the micronutrient content in soil is often insufficient to ensure maximum productivity, which creates the need for their application through fertilizers. This study compared the availability of zinc, boron, manganese and copper to the soil, their absorption, accumulation and effect in developing maize plants, supplied as granules mixed with NPK granules or as powder, coating NPK granules. The experiment was conducted in a greenhouse, in a randomized block design with four replications, using a soil classified as Oxisol and maize hybrid AG1051. The formulation for fertilizers used was 4-30-10 $\left(\mathrm{N}-\mathrm{P}_{2} \mathrm{O}_{5}-\mathrm{K}_{2} \mathrm{O}\right)$ with $0.3 \%$ zinc, $0.1 \%$ boron, $0.2 \%$ manganese and $0.2 \%$ copper applied at doses of $0,150,300,600,1200$ and $2400 \mathrm{~kg} \mathrm{ha}^{-1}$, furthermore, doses of 4-30-10 without micronutrients were applied to ensure variation only for micronutrient doses. Coating NPK granules with micronutrients was better than the mixture for soil Zn content, zinc concentration and accumulation in the shoot and dry mass production. Both fertilizers presented similar behavior for soil B content, B concentration and accumulation in shoots. However, for the greatest dose, B results were better for the mixture of granules. The addition of $\mathrm{Mn}$ and $\mathrm{Cu}$ to NPK formulation resulted in no response in the soil, although the mixture resulted in greater concentration of $\mathrm{Mn}$ in the shoot and coating granules showed greater accumulation of $\mathrm{Cu}$.
\end{abstract}

KEYWORDS: Zea mays. Coating granules. Zinc. Boron.

\section{INTRODUCTION}

There are seven micronutrients $(\mathrm{B}, \mathrm{Cl}, \mathrm{Cu}$, $\mathrm{Fe}, \mathrm{Mn}, \mathrm{Mo}$ and $\mathrm{Zn}$ ) satisfying the essentiality criteria and are, therefore, considered essential for plant development (VALE, 2000); however, the low natural levels of micronutrients in soils are insufficient to guarantee maximum yields. Hence, these elements are obtained in nature, undergo industrial purification, and then converted into commercial fertilizers (MONTEIRO FILHO, 2005).

In maize, the amounts required for a grain production of $9 \mathrm{t} \mathrm{ha}^{-1}$ are approximately $400 \mathrm{~g} \mathrm{Zn}$, $170 \mathrm{~g} \mathrm{~B}, 340 \mathrm{~g} \mathrm{Mn}$ and $110 \mathrm{~g} \mathrm{Cu}$, among others (COELHO; FRANÇA, 2013). The main role of these four micronutrients in this crop include $\mathrm{Zn}$ as enzyme activator, precursor of amino acids and hormones and participant in tissue growth process, which means that maize is one of the crops with fastest responses to $\mathrm{Zn}$ application, providing gains in dry matter and grain production. Boron is essential for pollen grain germination and pollen tube formation, so the cobs of $\mathrm{B}$ deficient maize plants are typically curved, since the uniformity of their growth is related to the formation of the grains. Manganese acts on the synthesis of secondary metabolites and amino acids, while $\mathrm{Cu}$ is an important enzyme activator with vital role in photosynthesis, respiration, metabolism of carbohydrates and proteins and cell wall formation (FAVARIN et al., 2008).

Because of the small doses applied, uniformity in micronutrient application may be a problem. Thus, the supply of micronutrients aggregated to NPK formulations has become an important nutrient management practice (RESENDE, 2005). For example, mixtures of micronutrient granules with NPK granules, one of the most used forms for soil application (LOPES, 1999), presents an easy way of obtaining formulations (ABREU et al., 2007), but also has segregation problems (MORTVEDT, 1991; MORTVEDT and GILKES, 1993; LOPES, 1999).

Segregation is the separation of particles which comprise the mixture of fertilizers in order of particle size, as a result of particle size distribution and favored by the difference of particle sizes, which can occur with solid fertilizers (RODELLA, 2000). Accordingly, Carvalho (2001) showed segregation of the fertilizer components both in granule mix as the granulated mixture, having the 
most noticeable effect of chemical segregation in combination with micronutrient granules.

Knowing that segregation can be minimized with the quality control of products entering the composition of mixtures and particles having uniform size (RODELLA, 2000) to improve the micronutrient application quality, one option would be coating NPK granules with micronutrients applied as fine powder (ABREU et al., 2007). However, there is little research on micronutrient efficiency associated with NPK fertilizers in different ways, and especially evaluating the granule coating technique (VOLKWEISS, 1991; LOPES, 1999; RESENDE, 2005; ABREU et al., 2007).

Thus, this study compared the availability of $\mathrm{Zn}, \mathrm{Mn}, \mathrm{B}$ and $\mathrm{Cu}$ in soil, their absorption, accumulation and effect on initial maize development, from granules mixed with NPK granules or from powder coating the NPK granules.

\section{MATERIAL AND METHODS}

The experimental design was randomized blocks, as a $2 \times 5+1$ factorial, with two fertilizers with micronutrients added by different forms (granules mixed with NPK granules or powder coating NPK granules), five doses $(150,300,600$, 1200 and $2400 \mathrm{~kg} \mathrm{ha}^{-1}$ ) and an additional treatment with no micronutrient fertilization, with four replications. The doses were supplemented in order that all treatments would receive the equivalent to $2400 \mathrm{~kg} \mathrm{ha}^{-1}$ of the formulations, and, therefore, the same dose of $\mathrm{N}, \mathrm{P}_{2} \mathrm{O}_{5}$ and $\mathrm{K}_{2} \mathrm{O}$, only varying the amounts of $\mathrm{Zn}, \mathrm{B}, \mathrm{Cu}$ and $\mathrm{Mn}$ (Table 1).

Table 1. Type of fertilizer and amount of nutrients supplied to the soil by each treatment.

\begin{tabular}{|c|c|c|c|c|c|c|c|c|c|}
\hline \multicolumn{3}{|c|}{ Formula NPK } & \multicolumn{7}{|c|}{ Nutrients } \\
\hline \multicolumn{2}{|c|}{ With micronutrients } & \multirow{2}{*}{$\begin{array}{c}\text { Without } \\
\text { micronutrients }\end{array}$} & \multirow{2}{*}{$\mathrm{N}$} & \multirow{2}{*}{$\mathrm{P}_{2} \mathrm{O}_{5}$} & \multirow{2}{*}{$\mathrm{K}_{2} \mathrm{O}$} & \multirow{2}{*}{$\mathrm{Zn}$} & \multirow{2}{*}{ B } & \multirow{2}{*}{$\mathrm{Mn}$} & \multirow{2}{*}{$\mathrm{Cu}$} \\
\hline Mixture & Coating & & & & & & & & \\
\hline & & - & & & & & & & \\
\hline 0 & 0 & 2400 & 96 & 720 & 240 & 0 & 0 & 0 & 0 \\
\hline 150 & 0 & 2250 & 96 & 720 & 240 & 0.4 & 0.1 & 0.3 & 0.3 \\
\hline 300 & 0 & 2100 & 96 & 720 & 240 & 0.9 & 0.3 & 0.6 & 0.6 \\
\hline 600 & 0 & 1800 & 96 & 720 & 240 & 1.8 & 0.6 & 1.2 & 1.2 \\
\hline 1200 & 0 & 1200 & 96 & 720 & 240 & 3.6 & 1.2 & 2.4 & 2.4 \\
\hline 2400 & 0 & 0 & 96 & 720 & 240 & 7.2 & 2.4 & 4.8 & 4.8 \\
\hline 0 & 150 & 2250 & 96 & 720 & 240 & 0.4 & 0.1 & 0.3 & 0.3 \\
\hline 0 & 300 & 2100 & 96 & 720 & 240 & 0.9 & 0.3 & 0.6 & 0.6 \\
\hline 0 & 600 & 1800 & 96 & 720 & 240 & 1.8 & 0.6 & 1.2 & 1.2 \\
\hline 0 & 1200 & 1200 & 96 & 720 & 240 & 3.6 & 1.2 & 2.4 & 2.4 \\
\hline 0 & 2400 & 0 & 96 & 720 & 240 & 7.2 & 2.4 & 4.8 & 4.8 \\
\hline
\end{tabular}

The fertilizers used were NPK without micronutrients (mixture of granules), NPK with granulated micronutrients (mixture of granules) and NPK with micronutrients coating the granules. All fertilizers had the formulation 4-30-10, formulated with mono-ammonium phosphate $(10 \% \mathrm{~N}$ and $54 \%$ $\left.\mathrm{P}_{2} \mathrm{O}_{5}\right)$, simple superphosphate $\left(18 \% \mathrm{P}_{2} \mathrm{O}_{5}\right)$, triple superphosphate $\left(46 \% \mathrm{P}_{2} \mathrm{O}_{5}\right)$ and potassium chloride $\left(60 \% \mathrm{~K}_{2} \mathrm{O}\right)$ granulated (grains with maximum $4 \%$ retained in 4-mm screen and 5\% passing through 1$\mathrm{mm}$ screen). The proportion of micronutrients in both fertilizers containing them was $0.3 \% \mathrm{Zn}, 0.1 \%$ $\mathrm{B}, 0.2 \% \mathrm{Cu}$ and $0.2 \% \mathrm{Mn}$, determined according to the production conditions at the industry and, therefore, chosen by the manufacturer.

The fertilizer containing granulated micronutrients was formulated with acidified zinc oxide $(25 \% \mathrm{Zn}$, and $70 \%$ solubility in water), acidified ulexite $(10 \% \mathrm{~B}$, and $90 \%$ solubility in water), acidified manganese oxide (20\% total Mn, and $75 \%$ solubility in water) and acidified copper oxide $(2.5 \% \mathrm{Cu}$, and $80 \%$ solubility in water) granulated before mixing with the granules of NPK. Copper oxide and manganese oxide were granulated together, and all of them had grain size of maximum $4 \%$ retained in 4-mm screen and 5\% passing through 1-mm screen.

The fertilizer coated with micronutrients was formulated with zinc oxide $(80 \%$ total $\mathrm{Zn})$, ulexite (15.5\% total B), manganese oxide (50\% total $\mathrm{Mn})$ and copper oxide (25\% total $\mathrm{Cu}$ ) finely ground (100\% passing through $0.15-\mathrm{mm}$ screen). Adhesion of the powder to the NPK granules was done with an aggregating agent and vegetable oil.

The experiment was done in a greenhouse with soil samples obtained from the $0-20 \mathrm{~cm}$ layer of a soil classified as Oxisol (Soil Survey Staff, 2013.), medium texture (195 $\mathrm{g} \mathrm{kg}^{-1}$ clay) (EMBRAPA, 1997), with 0.7, 0.08, 3.8 and $1.5 \mathrm{mg}$ 
$\mathrm{kg}^{-1}$ of $\mathrm{Zn}, \mathrm{B}, \mathrm{Mn}$ and $\mathrm{Cu}$, respectively (RAIJ et al., 2001).

The soil was subjected to incubation for 30 days with $0.6 \mathrm{~g} \mathrm{CaCO}_{3}$ (analysis grade - A.G.) $\mathrm{kg}^{-1}$ soil and $0.25 \mathrm{~g} \mathrm{MgSO}_{4}$ (A.G.) $\mathrm{kg}^{-1}$ soil to achieve a $\mathrm{Ca}: \mathrm{Mg}$ ratio around $3: 1$ and the base saturation around $70 \%$. The soil was maintained near $80 \%$ field capacity by adding water at $84 \mathrm{~mL} \mathrm{~kg}^{-1}$ soil, complementing its initial moisture that was $87.5 \mathrm{~mL}$ $\mathrm{H}_{2} \mathrm{O} \mathrm{kg}{ }^{-1}$ soil. This moisture (approximately 80\% field capacity) was maintained during the entire period of the experiment conduction.

At sowing, the treatments were applied to the total amount of soil in each plot $(5 \mathrm{~kg})$, that was already dry, weighed and inside plastic 5-L pots. The water was applied at $160 \mathrm{~mL} \mathrm{H}_{2} \mathrm{O} \mathrm{kg}^{-1}$ soil and 10 maize seeds (hybrid AG1051) were sown per pot. The equivalent of $80 \mathrm{~kg} \mathrm{ha}^{-1}$ of $\mathrm{S}$ was subsequently applied using $\mathrm{MgSO}_{4} \cdot 7 \mathrm{H}_{2} \mathrm{O}$ solution with $30.75 \mathrm{~g} \mathrm{~L}^{-1}$ concentration and dose of $10 \mathrm{~mL}$ $\mathrm{kg}^{-1}$ soil.

Seven days after sowing (DAS), the three best seedlings were kept in the pots. At 11 DAS and weekly thereafter, $\mathrm{N}$ fertilization was applied using a $\left(\mathrm{NH}_{4}\right)_{2} \mathrm{SO}_{4}$ solution with $50 \mathrm{~g} \mathrm{~L}^{-1}$ concentration applied at dose of $10 \mathrm{~mL} \mathrm{~kg}^{-1}$ soil.

Plant shoots were cut at the end of the experiment, placed in paper bags and dried in forced air circulation oven at $60^{\circ} \mathrm{C}$ until constant weight, which was obtained five days after harvest. Subsequently, shoots were weighed in an analytical scale.

Plant shoots were ground in a Willey mill and kept in plastic bags before analysis of $\mathrm{Zn}, \mathrm{B}$, $\mathrm{Mn}$ and $\mathrm{Cu}$, which were determined according to Malavolta et al. (1997). Micronutrient accumulation was estimated using the results of dry matter and the contents determined. Also, with the aid of a soil sampler for pots, soil samples were collected, air dried, sieved and placed in plastic bags. Soil analyses of $\mathrm{Zn}, \mathrm{B}, \mathrm{Mn}$ and $\mathrm{Cu}$ were done as described by Raij et al. (2001).

Data from qualitative treatments were submitted to analysis of variance with the software ASSISTAT (SILVA; AZEVEDO, 2002). Averages were compared by Tukey's and Dunnett's tests at 0.01 and 0.05 significance, respectively. Data from the quantitative treatments were submitted to analysis of variance and regression at 0.05 significance with SISVAR software (FERREIRA, 2008).

\section{RESULTS AND DISCUSSION}

\section{Soil micronutrients}

The application of the fertilizer containing micronutrients coating the granules was able to increase the soil $\mathrm{Zn}$ content at 3.6 and $7.2 \mathrm{~kg} \mathrm{ha}^{-1} \mathrm{Zn}$ doses (Table 2). These doses raised the soil $\mathrm{Zn}$ content, moving it from "LOW" (less than $0.9 \mathrm{mg}$ $\mathrm{dm}^{-3}$ ), to "HIGH" (above $2.0 \mathrm{mg} \mathrm{dm}^{-3}$ ), according to the classification proposed by Alvarez et al. (1999), which certainly favored plant development.

Regarding the sources tested, application of $\mathrm{Zn}$ in the form of granule coating resulted in soil $\mathrm{Zn}$ content greater than those obtained by their application in the form of mixture (Table 2). These results can be related to results of Galrão (1986), who states that a single broadcast application of $\mathrm{Zn}$ at $6.0 \mathrm{~kg} \mathrm{ha}^{-1}$, with incorporation in total area, was enough for four maize crops in a soil classified as dark-red clay oxisol. Moreover, that author observed differences between oxide, sulfate and frits as $\mathrm{Zn}$ sources for maize, which allows inferring that the oxide, even though having lower solubility in water, can be a good source of this micronutrient.

Table 2. Contents of $\mathrm{Zn}, \mathrm{B}, \mathrm{Mn}$ and $\mathrm{Cu}$ in the soil 28 days after the application of fertilizers containing them in mixture or coating NPK granules.

\begin{tabular}{|c|c|c|c|c|c|c|c|c|c|c|c|}
\hline \multicolumn{4}{|c|}{ Dose } & \multicolumn{2}{|c|}{$\mathrm{Zn}$} & \multicolumn{2}{|c|}{ B } & \multicolumn{2}{|c|}{$\mathrm{Mn}$} & \multicolumn{2}{|c|}{$\mathrm{Cu}$} \\
\hline $\mathrm{Zn}$ & $B$ & $\mathrm{Mn}$ & $\mathrm{Cu}$ & $\mathrm{M}$ & $\bar{C}$ & $\mathrm{M}$ & $\bar{C}$ & $\mathrm{M}$ & $\bar{C}$ & $\mathrm{M}$ & $\bar{C}$ \\
\hline \multicolumn{4}{|c|}{$-\mathrm{kg} \mathrm{ha}^{-1}-$} & \multirow{2}{*}{\multicolumn{2}{|c|}{0.7}} & - & $--\mathrm{mg} \mathrm{dm}$ & & & & \\
\hline 0 & 0 & 0 & 0 & & & \multicolumn{2}{|c|}{0.07} & \multicolumn{2}{|c|}{8.2} & \multicolumn{2}{|c|}{0.8} \\
\hline 0.4 & 0.1 & 0.3 & 0.3 & $0.7 \mathrm{a}$ & $1.0 \mathrm{a}$ & $0.08 \mathrm{a}$ & $0.08 \mathrm{a}$ & 10.9 & 10.5 & 0.9 & 0.9 \\
\hline 0.9 & 0.3 & 0.6 & 0.6 & $0.7 \mathrm{a}$ & $1.0 \mathrm{a}$ & $0.06 \mathrm{a}$ & $0.08 \mathrm{a}$ & 9.1 & 8.9 & 0.9 & 0.8 \\
\hline 1.8 & 0.6 & 1.2 & 1.2 & $0.7 \mathrm{a}$ & $0.9 \mathrm{a}$ & $0.09 \mathrm{a}$ & $0.08 \mathrm{a}$ & 12.3 & 10.7 & 0.8 & 0.9 \\
\hline 3.6 & 1.2 & 2.4 & 2.4 & $0.7 \mathrm{~b}$ & $2.3 * \mathrm{a}$ & $0.06 \mathrm{~b}$ & $0.13 \mathrm{a}$ & 8.3 & 13.4 & 0.8 & 0.9 \\
\hline 7.2 & 2.4 & 4.8 & 4.8 & $0.8 \mathrm{~b}$ & $2.1 * \mathrm{a}$ & $0.24 * \mathrm{a}$ & $0.15 * b$ & 8.7 & 12.8 & 0.8 & 0.9 \\
\hline & $\mathrm{A}$ & & & 0.7 & 1.5 & 0.11 & 0.10 & $0.11 \mathrm{a}$ & $0.10 \mathrm{a}$ & $0.8 \mathrm{a}$ & $0.9 \mathrm{a}$ \\
\hline
\end{tabular}

$\mathrm{M}=$ Mixture; $\mathrm{C}=$ Coating. Averages followed by different letters in the rows are different by Tukey's test at 0.01 of significance; * significant by Dunnett's test at 0.05 of significance compared to the control treatment. 
The initial level of B was "VERY LOW" (less than $0.15 \mathrm{mg} \mathrm{dm}^{-3}$ ) according to Alvarez et al. (1999), resulting in an increase from $0.07 \mathrm{mg} \mathrm{dm}^{-3}$ to up to $0.24 \mathrm{mg} \mathrm{dm}^{-3}$ for the greatest doses used (Table 2). The fertilizer comparison shows that the greatest levels of soil B were obtained by applying B coated NPK granules at $1.2 \mathrm{~kg} \mathrm{ha}^{-1}$ or in the mixture form at $2.4 \mathrm{~kg} \mathrm{ha}^{-1} \mathrm{~B}$ (Table 2).

Soil levels of $\mathrm{Mn}$ and $\mathrm{Cu}$, even without their application, was classified, respectively, as "GOOD" and "MEDIUM", according to Alvarez et al. (1999), which explains the lack of response to treatments (Table 2).

The study of doses, in turn, indicates that the application of increasing doses of $\mathrm{Zn}$ coating NPK granules increased levels of this nutrient in the soil (Figure 1). The increase in soil $\mathrm{Zn}$ content when applied coating NPK granules can be explained by Mortvedt (1992) stating that the granular form of $\mathrm{Zn}$ oxide has lower efficiency when compared to the powder form due to the lower specific surface and because it is a source with low solubility in water (MORTVEDT; GILKES, 1993).



Figure 1. Zinc contents in soil 28 days after application of increasing doses of fertilizers containing it in the form of NPK granule mixture, or as a coating of NPK granules.

Also, increasing $\mathrm{B}$ doses resulted in $\mathrm{B}$ dose applied in the form of mixture resulted in increasing availability of B in the soil, regardless of its form in the fertilizer. However, only the greatest greater level in comparison to B coating NPK granules (Figure 2).

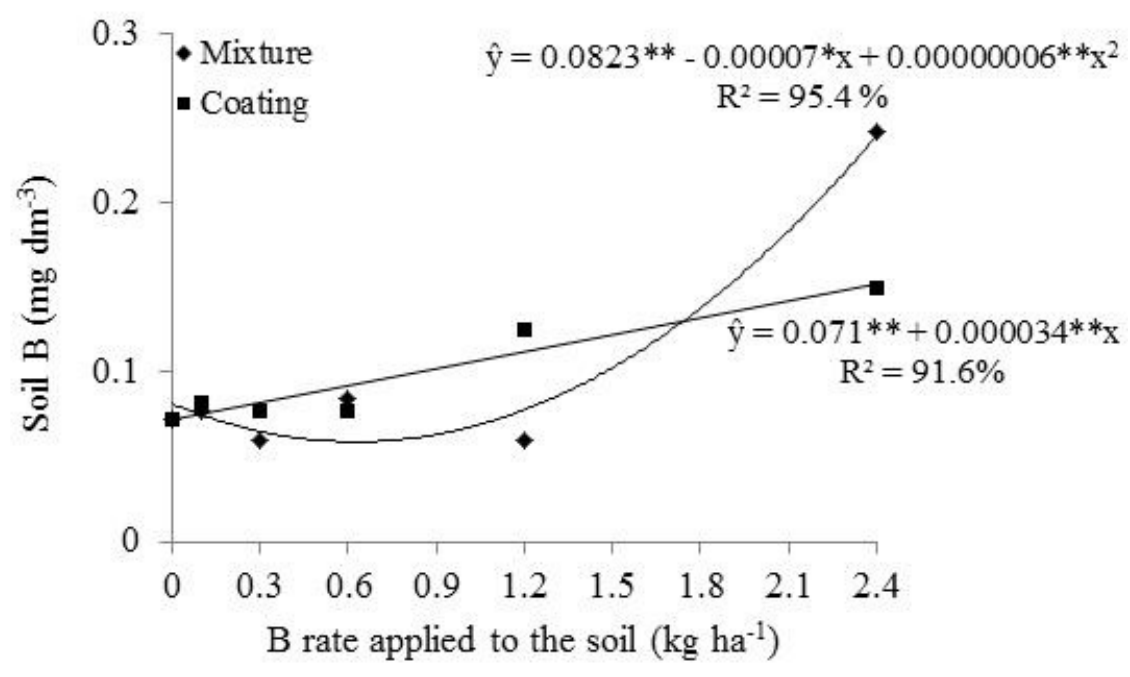

Figure 2. Boron contents in soil 28 days after application of increasing doses of fertilizers containing it in the form of NPK granule mixture, or as a coating of NPK granules. 


\section{Dry matter production}

Only the greatest dose of $\mathrm{Zn}, \mathrm{B}, \mathrm{Mn}$ and $\mathrm{Cu}$ as coating NPK granules produced maize plants with more dry matter than the control treatment (Table 3). Micronutrients coating NPK granules resulted in greater dry matter average than that found in the treatment with the mixture of micronutrients and NPK granules (Table 3 ).

These results differ from those found by Korndörfer et al. (1987), who tested methods of adding $\mathrm{Zn}$ as oxide and sulfate to the 5-30-15 fertilizer and observed similar results for both sources of $\mathrm{Zn}$ for dry matter production of maize shoots in a greenhouse experiment. Korndörfer et al. (1995) also found no difference in corn production for treatments without $\mathrm{Zn}$ and with $\mathrm{Zn}$ applied as oxide or in 4-30-10 formula with Zn added by FTE as mixture or incorporation.

The study of doses shows that increasing the applied amount of micronutrients coating NPK granules increased plant dry matter production, which did not occur for the micronutrients in the form of mixture (Figure 3).

Table 3. Dry matter of maize shoots 28 days after the application of fertilizers containing $\mathrm{Zn}, \mathrm{B}, \mathrm{Mn}$ and $\mathrm{Cu}$ in mixture or coating NPK granules.

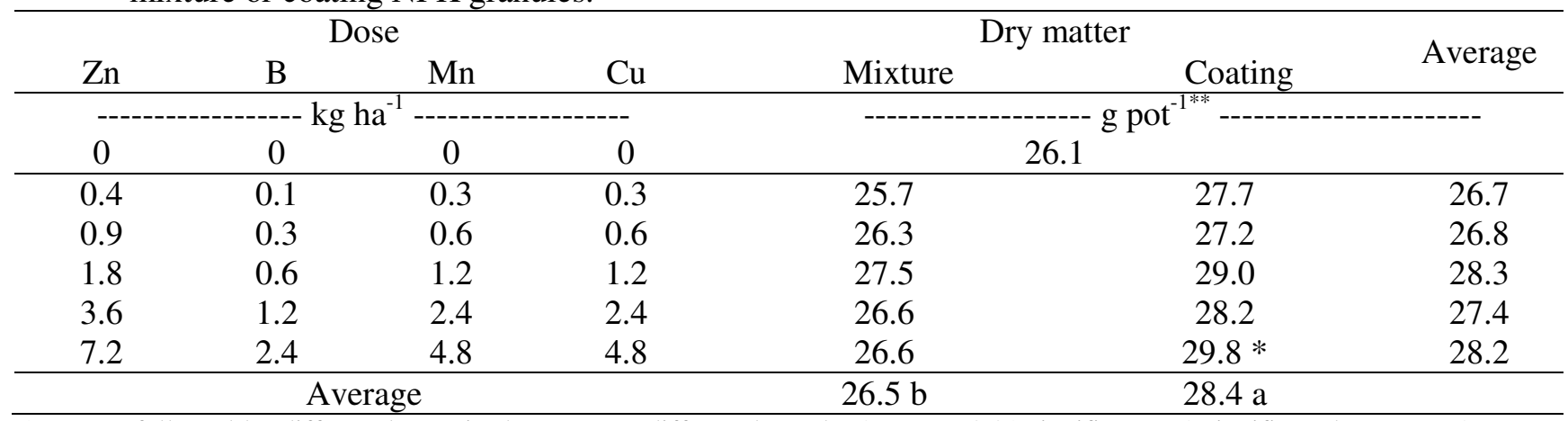

Averages followed by different letters in the rows are different by Tukey's test at 0.01 significance; * significant by Dunnett's test at 0.05 of significance compared to the control treatment. ** Average of five plants.

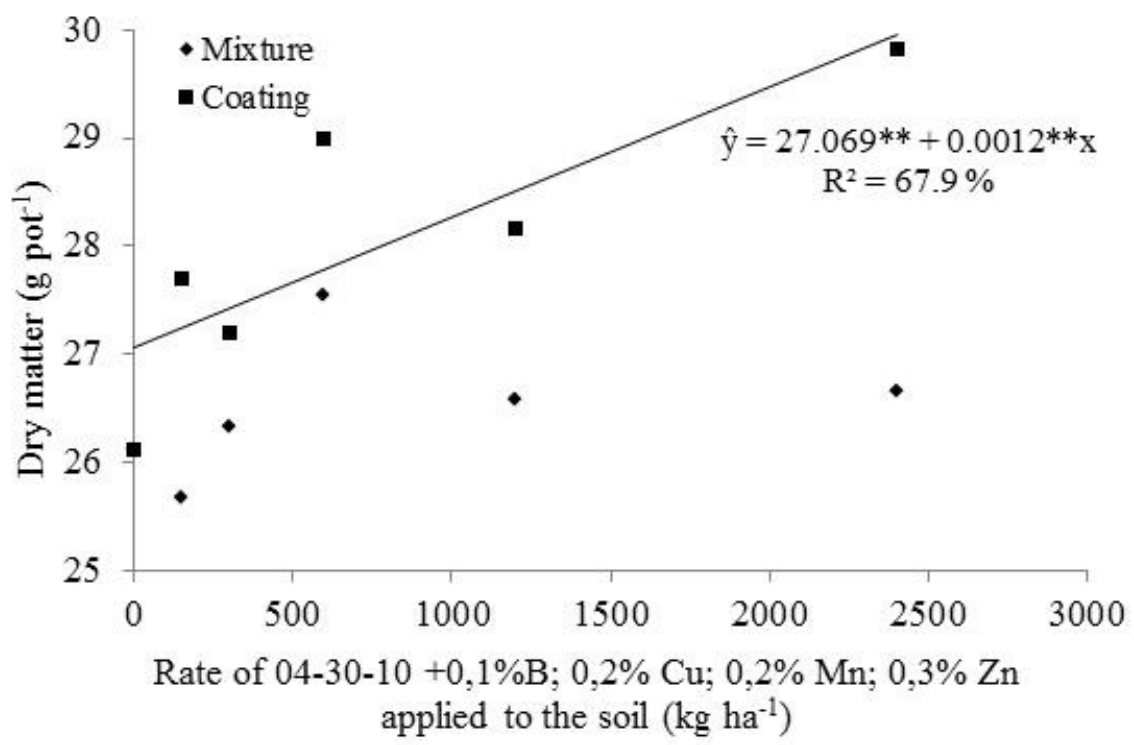

Figure 3. Dry matter of maize plants harvested 28 days after sowing as a function of the application of fertilizers containing $\mathrm{Zn}, \mathrm{B}, \mathrm{Mn}$ and $\mathrm{Cu}$ in the form of mixture or coating NPK granules.

\section{Micronutrients content and uptake by corn shoots}

Application of $\mathrm{Zn}$ at 3.6 and $7.2 \mathrm{~kg} \mathrm{ha}^{-1}$ coating NPK granules resulted in Zn shoot content of 30.5 and $36.7 \mathrm{mg} \mathrm{kg}^{-1}$, respectively, results that are greater than the control $\left(22.1 \mathrm{mg} \mathrm{kg}^{-1}\right)$, and also in comparison to the micronutrients as mixture of granules at the same doses (22.2 and $24.5 \mathrm{mg} \mathrm{kg}^{-1}$, respectively) (Table 4). 
Table 4. Zinc, B, $\mathrm{Mn}$ and $\mathrm{Cu}$ content in maize shoots 28 days after the application of fertilizers containing them in mixture or coating NPK granules.

\begin{tabular}{|c|c|c|c|c|c|c|c|c|c|c|c|}
\hline \multirow{2}{*}{\multicolumn{4}{|c|}{ Dose }} & \multicolumn{8}{|c|}{ Content } \\
\hline & & & & \multicolumn{2}{|c|}{$\mathrm{Zn}$} & \multicolumn{2}{|c|}{ B } & \multicolumn{2}{|c|}{$\mathrm{Mn}$} & \multicolumn{2}{|c|}{$\mathrm{Cu}$} \\
\hline $\mathrm{Zn}$ & B & $\mathrm{Mn}$ & $\mathrm{Cu}$ & M & $\mathrm{C}$ & M & $\mathrm{C}$ & M & $\mathrm{C}$ & M & $\mathrm{C}$ \\
\hline \multicolumn{4}{|l|}{-} & \multirow{2}{*}{\multicolumn{2}{|c|}{22.1}} & & mg k & \multirow{2}{*}{\multicolumn{2}{|c|}{114}} & & \\
\hline 0 & 0 & 0 & 0 & & & \multicolumn{2}{|c|}{6.1} & & & \multicolumn{2}{|c|}{6.6} \\
\hline 0.4 & 0.1 & 0.3 & 0.3 & $22.4 \mathrm{a}$ & $21.2 \mathrm{a}$ & $5.7 \mathrm{a}$ & $7.3 \mathrm{a}$ & 109 & 97.3 & 6.2 & 7.1 \\
\hline 0.9 & 0.3 & 0.6 & 0.6 & $23.1 \mathrm{a}$ & $24.6 \mathrm{a}$ & $6.1 \mathrm{a}$ & $5.6 \mathrm{a}$ & 112 & 110 & 6.5 & 7.2 \\
\hline 1.8 & 0.6 & 1.2 & 1.2 & $23.9 \mathrm{a}$ & $26.2 \mathrm{a}$ & $10.6 \mathrm{a}$ & $7.4 \mathrm{a}$ & 119 & 105 & 6.8 & 6.6 \\
\hline 3.6 & 1.2 & 2.4 & 2.4 & $22.2 b$ & $30.5 * \mathrm{a}$ & $11.8 * \mathrm{a}$ & $11.1 \mathrm{a}$ & 106 & 99.3 & 6.6 & 6.1 \\
\hline 7.2 & 2.4 & 4.8 & 4.8 & $24.5 b$ & $36.7 * \mathrm{a}$ & $27.2 * \mathrm{a}$ & $16.0 * \mathrm{~b}$ & 114 & 96.7 & 6.3 & 6.1 \\
\hline \multicolumn{4}{|c|}{ Average } & 23.2 & 27.9 & 12.3 & 9.5 & $112 \mathrm{a}$ & $102 \mathrm{~b}$ & $6.5 \mathrm{a}$ & $6.6 \mathrm{a}$ \\
\hline
\end{tabular}

$\mathrm{M}=$ Mixture; $\mathrm{C}=$ Coating. Averages followed by different letters in the rows are different by Tukey's test at 0.01 of significance; * significant by Dunnett's test at 0.05 of significance compared to the control treatment.

These results corroborate those found by Judy et al. (1964) and Allen and Terman (1966) who claim that the granular $\mathrm{ZnO}$ was inefficient for maize grown in the greenhouse, and bean crop grown on the field, respectively. In general, $\mathrm{Zn}$ absorption was high and its concentration in the shoots were above the minimum adequate level for development of maize plants (15 mg kg-1), according to Büll (1993).

The results for shoot $\mathrm{B}$ content ranged from 5.6 to $27.2 \mathrm{mg} \mathrm{kg}^{-1}$, and the doses of 1.2 and $2.4 \mathrm{~kg}$ $\mathrm{ha}^{-1}$ in the form of mixture and $2.4 \mathrm{~kg} \mathrm{ha}^{-1}$ in the form of coating generated better results than the control (Table 4). It was also observed that the B content of $27.2 \mathrm{mg} \mathrm{kg}^{-1}$ for the highest dose, was greater for B applied as a mixture than as coating (Table 4), but both results were classified as suitable for maize (greater than $15 \mathrm{mg} \mathrm{kg}^{-1}$ ) according to Büll (1993).

Manganese doses used did not affect its absorption and uptake by maize plants (Tables 4 and 5). This lack of response can be explained by the high concentration of $\mathrm{Mn}$ in control plants, which were within the ideal range (42 to $150 \mathrm{mg} \mathrm{kg}^{-1}$ ) according to Büll (1993) (Table 4). In contrast to the doses, the method of addition of Mn to the NPK fertilizer influenced shoot $\mathrm{Mn}$ content, and the mixture of granules resulted in greater Mn content (112 $\mathrm{mg} \mathrm{kg}^{-1}$ ) compared to coating, which presented the average of $102 \mathrm{mg} \mathrm{kg}^{-1}$ (Table 4). This result differs from those obtained by Mortvedt (1991), who claimed that granulated manganese oxide was not efficient for oat, corn and soybean crops.

Copper doses, as well as its form in the fertilizer, did not affect its absorption (Table 4); however, uptake by plants treated with $\mathrm{Cu}$ as coating accumulated greater amounts of this element (Table 5). One possible explanation for the lack of response to $\mathrm{Cu}$ in the shoots could be the fact that even plants that had not received $\mathrm{Cu}$ application presented acceptable shoot $\mathrm{Cu}$ levels for maize, in the range 6-20 $\mathrm{mg} \mathrm{kg}^{-1}$ (BÜLL, 1993; MARTINEZ et al., 1999).

Zinc uptake, in the form of coating of granules in the three greatest doses resulted in greater amounts $\left(756,855\right.$ and $1094 \mu \mathrm{g} \mathrm{Zn} \mathrm{pot}{ }^{-1}$, respectively) as compared to plants that did not received $\mathrm{Zn}$ application $\left(578 \mu \mathrm{g} \mathrm{Zn} \mathrm{pot}^{-1}\right)$ (Table 5). The two greatest doses of this group resulted in the greatest $\mathrm{Zn}$ uptake compared to the same amount of $\mathrm{Zn}$ applied as mixture, with 589 and $654 \mu \mathrm{g} \mathrm{Zn}$ pot $^{-}$ ${ }^{1}$, respectively (Table 5).

Boron uptake, at the the two greatest doses, resulted in greater values than in plants from the control treatment (Table 5). However, the greatest dose of B in the mixture of granules resulted in the greatest uptake compared to the coating of granules (Table 5).

The effects of doses were observed for $\mathrm{Zn}$ and $\mathrm{B}$ and, for $\mathrm{Zn}$, only the application in the coating form caused an increase in shoot $\mathrm{Zn}$ content (Figure 4A) and uptake (Figure 4B). The greater $\mathrm{Zn}$ content and uptake from coating of granules, even from a water insoluble source (zinc oxide), was probably due to the availability of the nutrient as a result of the acidifying effect of superphosphates present in the formula, which causes very low $\mathrm{pH}$ around the granule (YOUNG, 1969; MORTVEDT; GIORDANO, 1969).

For both modes of micronutrient additon studied, increasing the dose of $\mathrm{B}$ resulted in greater shoot B content and greater B uptake (Figure 5), but the intensity of the increase was superior to $B$ in the form of mixture, as seen from the third greatest dose for shoot $\mathrm{B}$ content (Figure 5A); however, for $\mathrm{B}$ uptake it was noted that from the dose of $0.6 \mathrm{~kg} \mathrm{ha}^{-1}$ , for each $\mathrm{kg} \mathrm{ha}^{-1}$ applied as mixture of granules, the 
increase in uptake of B was about 100 units greater than that found for the coating (Figure 5B).

Table 5. Zinc, B, Mn and $\mathrm{Cu}$ uptake by maize plants 28 days after the application of fertilizers containing them in mixture or coating NPK granules.

\begin{tabular}{|c|c|c|c|c|c|c|c|c|c|c|c|}
\hline \multirow{2}{*}{\multicolumn{4}{|c|}{ Dose }} & \multicolumn{8}{|c|}{ Uptake } \\
\hline & & & & \multicolumn{2}{|c|}{$\mathrm{Zn}$} & \multicolumn{2}{|c|}{ B } & \multicolumn{2}{|c|}{$\mathrm{Mn}$} & \multicolumn{2}{|c|}{$\mathrm{Cu}$} \\
\hline $\mathrm{Zn}$ & B & $\mathrm{Mn}$ & $\mathrm{Cu}$ & M & $\mathrm{C}$ & M & $\mathrm{C}$ & M & $\mathrm{C}$ & M & $\mathrm{C}$ \\
\hline \multicolumn{12}{|c|}{------ kg ha ${ }^{-1}$------- } \\
\hline 0 & 0 & 0 & 0 & \multicolumn{2}{|c|}{578} & & & \multicolumn{2}{|c|}{2981} & \multicolumn{2}{|c|}{171} \\
\hline 0.4 & 0.1 & 0.3 & 0.3 & $573 \mathrm{a}$ & $586 \mathrm{a}$ & $147 \mathrm{a}$ & $201 \mathrm{a}$ & 2818 & 2699 & 159 & 196 \\
\hline 0.9 & 0.3 & 0.6 & 0.6 & $608 \mathrm{a}$ & $665 \mathrm{a}$ & $160 \mathrm{a}$ & $152 \mathrm{a}$ & 2935 & 2987 & 172 & 195 \\
\hline 1.8 & 0.6 & 1.2 & 1.2 & $658 \mathrm{a}$ & $756 * a$ & $295 \mathrm{a}$ & $212 \mathrm{a}$ & 3253 & 3039 & 188 & 190 \\
\hline 3.6 & 1.2 & 2.4 & 2.4 & $589 \mathrm{~b}$ & $855 * \mathrm{a}$ & $315 * \mathrm{a}$ & $313 * a$ & 2806 & 2792 & 175 & 171 \\
\hline 7.2 & 2.4 & 4.8 & 4.8 & $654 b$ & $1094 * \mathrm{a}$ & $722 * a$ & $474 * b$ & 3040 & 2881 & 168 & 182 \\
\hline \multicolumn{4}{|c|}{ Average } & 616 & 791 & 328 & 271 & $2970 \mathrm{a}$ & $2879 \mathrm{a}$ & $172 \mathrm{~b}$ & $187 \mathrm{a}$ \\
\hline
\end{tabular}

$\mathrm{M}=$ Mixture; $\mathrm{C}=$ Coating. Averages followed by different letters in the lines are different by the Tukey test at 0.01 of significance; * significant by Dunnett's test at 0.05 of significance compared to the control treatment.

(A)

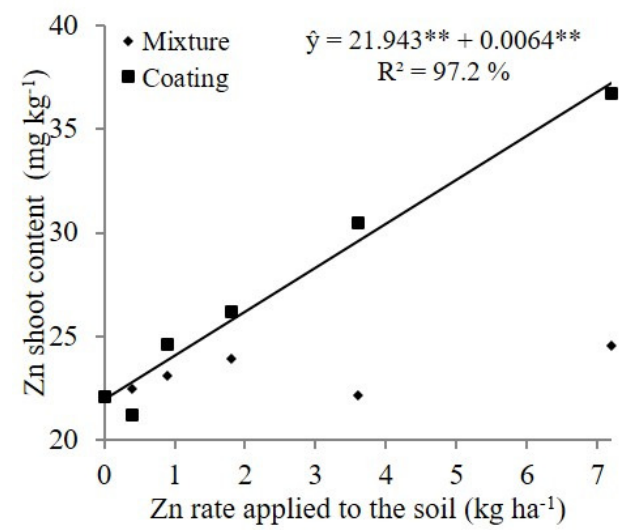

(B)

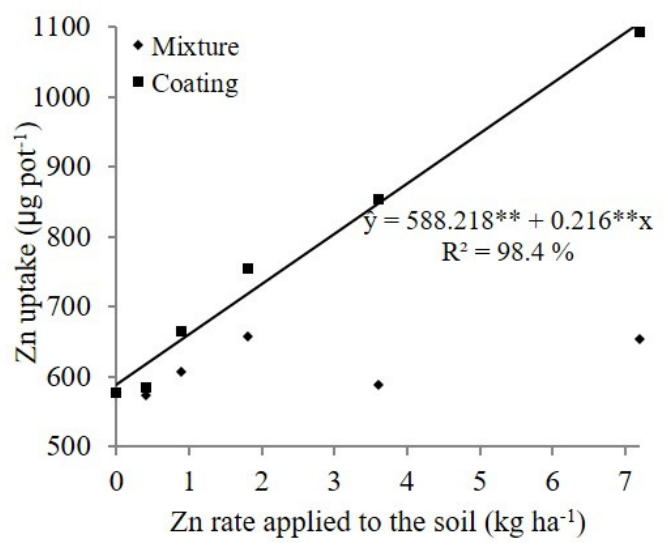

Figure 4. Zinc content (A) and uptake (B) by maize shoots 28 days after the application of increasing doses of fertilizers containing it in the form of NPK granule mixture, or as a coating of NPK granules.

(A)

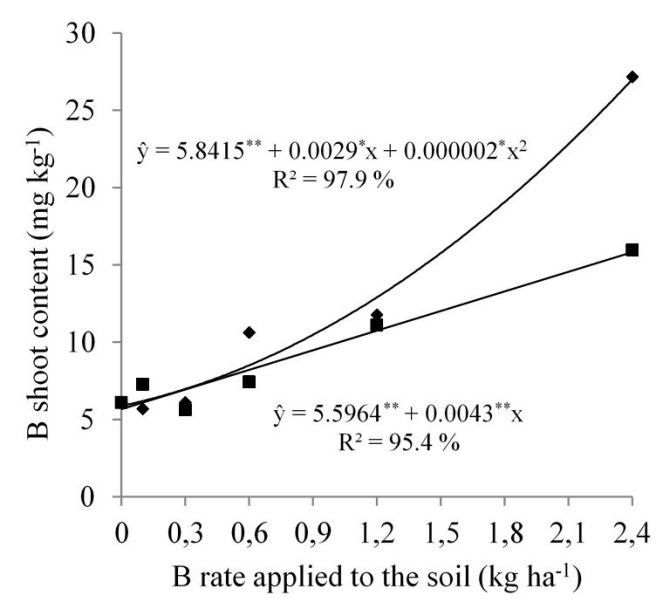

(B)

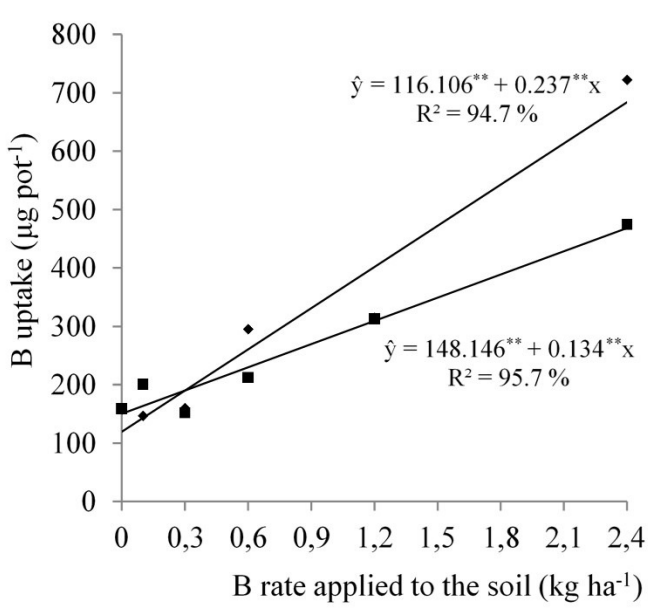

Figure 5. Boron content (A) and uptake (B) by maize shoots 28 days after the application of increasing doses of fertilizers containing it in the form of NPK granule mixture, or as a coating of NPK granules. 


\section{CONCLUSIONS}

Coating of NPK granules with micronutrients was better than the physical mixture of granulated micronutrient with NPK granules for soil $\mathrm{Zn}$ content, shoot $\mathrm{Zn}$ content and uptake and the dry matter production of maize plants.

The mixture of granular micronutrients with NPK granules presented similar behavior to the coating form for soil B content, shoot B content and B uptake.

The addition of $\mathrm{Mn}$ and $\mathrm{Cu}$ to the NPK formulation did not result in increase in their soil contents, but the mixture form did result in greater shoot Mn content and the coating form showed greater $\mathrm{Cu}$ uptake by maize plants.

RESUMO: Os micronutrientes são essenciais às plantas porém seus teores no solo podem não ser suficientes para altas produtividades, o que gera necessidade de aplicação via fertilizantes. Objetivou-se comparar a disponibilização de zinco, boro, manganês e cobre para o solo, sua absorção, acúmulo e efeito no desenvolvimento de plantas de milho, quando aplicados granulados e em mistura com grânulos NPK ou na forma de pó, revestindo grânulos de NPK. O experimento foi conduzido em casa de vegetação, com delineamento de blocos casualizados, com quatro repetições, com amostras de solo classificado como Latossolo Vermelho distrófico típico e híbrido de milho AG1051. Os fertilizantes utilizados foram de formulação 4-30-10 $\left(\mathrm{N}_{-} \mathrm{P}_{2} \mathrm{O}_{5}-\mathrm{K}_{2} \mathrm{O}\right)$ com $0,3 \%$ de zinco, $0,1 \%$ de boro, 0,2 \% de manganês e $0,2 \%$ de cobre aplicados nas doses de 0, 150, 300, 600, 1200 e $2400 \mathrm{~kg} \mathrm{ha}^{-1}$. Doses complementares de 4-30-10 sem micronutrientes foram aplicadas para que todos os tratamentos recebessem as mesmas doses de nitrogênio, fósforo e potássio, variando somente as doses dos micronutrientes. O revestimento dos grânulos de NPK com micronutrientes é superior à mistura quando se compara o teor de zinco no solo, a concentração e o acúmulo de zinco na parte aérea e a produção de massa seca das plantas de milho. A mistura de micronutrientes granulados com grânulos de NPK apresenta comportamento semelhante para os teores de boro no solo, sua concentração e acúmulo na parte aérea. A adição de manganês e cobre ao formulado NPK não resultou em resposta no solo, embora a forma de mistura tenha resultado em maior concentração de manganês na parte aérea, e o revestimento de grânulos tenha mostrado maior acúmulo de cobre pelas plantas de milho.

PALAVRAS-CHAVE: Zea mays. Revestimento de grânulos. Zinco. Boro.

\section{REFERENCES}

ABREU, C. A.; LOPES, A. S.; SANTOS, G. Micronutrientes. In: NOVAIS, R. F.; ALVAREZ, V. H.; BARROS, N. F.; FONTES, R. L. F.; CANTARUTTI, R. B.; NEVES, J. C. L. (Eds.). Fertilidade do solo. Viçosa: Sociedade Brasileira de ciência do solo, 2007. p. 645 - 736.

ALLEN, S. E.; TERMAN, G. L. Response of maize and sudangrass to zinc in granular micronutrients. In: INTERNATIONAL SOCIETY OF SOIL SCIENCE. 1966, Aberdeen. Transactions... Aberdeen:, ISSS, 1966. p. 255-266.

ALVAREZ, V. H.; NOVAIS, R. F.; BARROS, N. F.; CANTARUTTI, R. B.; LOPES, A. S. Interpretação dos resultados das análises de solos. In: RIBEIRO, A. C.; GUIMARÃES, P. T. G.; ALVAREZ, V. H. (Eds.). Recomendações para o uso de corretivos e fertilizantes em Minas Gerais - $5^{\text {a }}$ Aproximação. Viçosa: Comissão de Fertilidade do Solo do Estado de Minas Gerais, 1999. p. 143-167.

BÜLL, L. T.. Nutrição mineral do milho. In: BÜLL, L. T.; CANTARELLA, H. (Eds.). Cultura do milho: fatores que afetam a produtividade. Piracicaba: Potafós, 1993. p. 63-121

EMBRAPA (Empresa Brasileira de Pesquisa Agropecuária). Manual de métodos de análise de solo. 2. ed. Rio de Janeiro: Centro Nacional de Pesquisa de Solos, 1997. 212 p.

EMBRAPA (Empresa Brasileira de Pesquisa Agropecuária). Sistema brasileiro de classificação de solos. Rio de Janeiro: Centro Nacional de Pesquisa de Solos, 2009. 306 p. 
FERREIRA, D. F. Sisvar: um programa para análises e ensino de estatística. Revista Symposium, Recife, v.6, n. 2, p.36-41, jul./dez. 2008

GALRÃO, E. Z. Micronutrientes. In: GOEDERT, W. J. (Ed.). Solos dos Cerrados: tecnologias e estratégias de manejo. Planaltina: Embrapa-CPAC, 1986. p. 237-259.

JUDY, W.; LESSMAN, G.; ROZYCKA, T.; ROBERTSON, L.; ELLIS, B. G. Field and laboratory studies with zinc fertilization of pea beans. Quartely Bulletin, Michigan State University Agricultural Experiment Station, East Lansing, v. 46, p. 386-400. 1964.

KORNDÖRFER, G. H.; ALCÂNTARA, C. B.; HOROWITZ, N; LANA, R. M. Q. Formas de adição de zinco a um formulado NPK e seu efeito sobre a produção de milho. Scientia Agricola, Piracicaba, v.52, p. 555-560. 1995. https://doi.org/10.1590/S0103-90161995000300024

KORNDÖRFER, G. H.; EIMORI, I. E.; TELLECHEA, M. C. R. Efeito da técnica de adição de zinco a fertilizantes granulados na produção de matéria seca de milho. Revista Brasileira de Ciência do Solo, Viçosa, v. 11, p. 329-332. 1987.

LOPES, A. S. Micronutrientes: Filosofia de Aplicação e Eficiência Agronômica. São Paulo: Associação Nacional para a Difusão de Adubos, 1999. 58 p. (Boletim Técnico nº 8).

MALAVOLTA, E.; VITTI, G. C.; OLIVEIRA, S. A. Avaliação do estado nutricional das plantas: princípios e aplicações. 2. ed. Piracicaba: Associação Brasileira para Pesquisa da Potassa e do Fosfato. 1997. $319 \mathrm{p}$.

MARTINEZ, H. E. P.; CARVALHO, J. G.; SOUZA, R. B. Diagnose foliar. In: RIBEIRO, A. C.; GUIMARÃES, P. T. G.; ALVAREZ, V. H. (Eds.). Recomendações para o uso de corretivos e fertilizantes em Minas Gerais - $5^{\text {a }}$ Aproximação. Viçosa: Comissão de Fertilidade do Solo do Estado de Minas Gerais, 1999. p. 143-167.

MONTEIRO FILHO, M. Perigo invisível: resíduos tóxicos em micronutrientes: veneno na produção de alimentos. Revista Problemas Brasileiros, São Paulo, n. 371, set. 2005. Disponível em: < https://www.sescsp.org.br/online/artigo/3508_PERIGO+INVISIVEL> Acesso em: 12 set. 2012

MORTVEDT, J. J. Micronutrient fertilizer technology. In: MORTVEDT, J. J.; COX, F. R.; SHUMAN, L. M.; WELCH, R. M. (Eds.). Micronutrients in Agriculture. 2ed. Madison: Soil Science Society of America, 1991. p. 523-548. https://doi.org/10.2136/sssabookser4.2ed.c14

MORTVEDT, J. J. Crop response to level of water-soluble zinc in granular zinc fertilizers. Fertilizer Research, Cambridge, v.33, p. 249-255, 1992. https://doi.org/10.1007/BF01050880

MORTVEDT, J. J.; GILKES, R. J. Zinc Fertilizers. In: ROBSON, A. D. (Ed.). Zinc in Soils and Plants. Perth: The University of Western Australia, v. 55, 1993. p. 33-44. https://doi.org/10.1007/978-94-011-0878-2_3

MORTVEDT, J. J.; GIORDANO, P. M. Availability to corn of zinc applied with various macronutrients fertilizers. Soil Science, Baltimore, v.108, p. 180-187, 1969. https://doi.org/10.1097/00010694-19690900000006

RAIJ, B. V.; ANDRADE, J. C.; CANTARELLA, H.; QUAGGIO, J. A. (Eds.). Análise química para avaliação da fertilidade em solos tropicais. Campinas: Instituto Agronômico, 2001. 395 p.

RESENDE, A.V. Micronutrientes na agricultura brasileira: disponibilidade, utilização e perspectivas. Rio de Janeiro: Centro de Tecnologia Mineral. 2005. 37 p. (Série Estudos e Documentos). 
SILVA, F. A. S.; AZEVEDO, C. A. V. Versão do programa computacional Assistat para o sistema operacional. Revista Brasileira de Produtos Agroindustriais, Campina Grande, v. 4, n.1, p 71-78, 2002.

https://doi.org/10.15871/1517-8595/rbpa.v4n1p71-78

VALE, F. Avaliação e caracterização da disponibilidade de boro e zinco contidos em fertilizantes. 2000.

101 f. Tese (Doutorado em Agronomia), Escola Superior de Agricultura "Luiz de Quiroz", Universidade de São Paulo, Piracicaba, 2000.

VOLKWEISS, S. J. Fontes e métodos de aplicação. In: FERREIRA, M. E.; CRUZ, M. C. P. (Eds.).

Micronutrientes na agricultura. Piracicaba: Potafos / CNPq, 1991. p. 391-412.

YOUNG, R. Providing micronutrients in bulk-blend, granular fertilizers. Commercial Fertilizers, Atlanta, v. 118, n. 1, p. 21-24, 1969. 